\title{
THE IMPORTANCE OF THE WHOLESALE MARKETS FOR TRADE IN AGRICULTURAL PRODUCTS ${ }^{1}$
}

\author{
Boris Kuzman', Nedeljko Prdič3, Zoran Dobraš
}

\begin{abstract}
Summary
The main objective of this research is based on the importance of wholesale markets as special market institutions in trade in agro-industrial products. Based on communication knowledge about the retail market operations (wholesale gross markets), on the domestic market, as well as the importance given to wholesale markets in the developed countries from the aspect of trade, it is concluded that even domestic trade can increase selling these type of products at wholesale markets. The subject of research of this paper is concept of building wholesale markets as a substitute for retail trade (quantitative or wholesale gross markets) for agro-industrial products. This paper aims to achieve such a level of knowledge that will enable making quality decisions starting fromthe interests of businesses, traders and customers (consumers).
\end{abstract}

Key words: market, trade, agro-industrial products, wholesale markets, wholesale

JEL: Q13, M31

\section{Introduction}

Distribution of agricultural products must be adapted to the changes in the market environment. The importance of the market for agricultural products as a part of the overall product market takes a special place due to the specific nature of the production process in agriculture. The significance of the wholesale market is reflected in various activities related to the distribution and sale of agricultural products. The paper aims to emphasize the importance of the market for agricultural products for the development of the overall product market, which will

1 Paper is part of project III 46006 - Sustainable agriculture and rural development in function of achieving strategic goals of Republic of Serbia within Danube region, funded by Ministry of Education, Science and Technical Development of Republic of Serbia. Project period 2011-2015.

2 Boris Kuzman Ph.D., Research Associate, Institute of Agricultural Economics, Volgina Street no. 15, 11060 Belgrade, Serbia, E-mail: kuzmanboris@yahoo.com

3 Nedeljko Prdić Ph.D., JKP Tržnica, Novi Sad, Đorđa Servickog street no. 2a/6, Novi Sad, Serbia, Phone: 063/500-818, E-mail: ekonomistdoo@sbb.rs

4 Zoran Dobraš M.Sc., Association of Dystrophy and Related Diseases of Republika Srpska, Banja Luka, Republika Srpska, Phone: +38765 523 600; E-mail: zorandobras@gmail.com 
influence the selection of an adequate development strategy. Namely, in the market conditions of wholesale market operations, specialized market institutions in the commodity market represented the places which enable the meeting of a large number of buyers and sellers in one place in the wholesale trade of agricultural products. Wholesale markets are such markets and public systems that use closed and open spaces of city infrastructure. The problem that the research aims to resolve is determining the place and role of the wholesale market in the distribution of agricultural products, which will be reflected in the increase in trade in agricultural products and total income in the agro-industry.

When it comes to the importance of the wholesale market as a distribution channel, their role is becoming more and more important in the development of the market, but also their competitiveness in relation to various types of market centers must have a clearly profiled strategy of competitive advantage (Prdić, 2016).

This should also be the goal of Belgrade's wholesale market: attracting a large number of existing supermarkets, hypermarkets and discount centers to supply their needs in the field of fruits and vegetables, first and foremost, but also fresh meat, fish, etc. They should perform the sales at the Belgrade wholesale market (Lovreta, 2008).

The Wholesale Market is a special market institution that organizes wholesale trade through the regulation, maintenance and issuance of specialized space for displaying and selling fruits, vegetables and other agricultural and food products, other consumer goods, as well as the provision of accompanying services, and in particular the storage of goods, its processing, packaging and other services related to handling and transportation (Law on Trade of the Republic of Serbia).

Over 500 wholesalers operate at Belgrade's wholesale market. The wholesale market has a total of 866 outlets (on an area of 7ha) on the plateau and $6300 \mathrm{~m}^{2}$ of business and warehouse space (20 shops, 3 malls, 73 tents and 52 warehouses) (veletržnica.co.rs, 2017).

Nowadays, when awareness of the importance of nutrition and, therefore, the importance of arable land is growing, it is necessary to pay particular attention to the problem of the lack of funds in the context of agrarian production(Vojnović et al., 2017).

Competitive advantage on the market through superior value delivered to consumers is something that will last for a while. There are some indications that companies are moving in that direction. This change must be managed. This orientation will require that many companies that intend to follow it should reassess the organisational culture, organizational structure and management skills(Milisavljević, 2010).

The development program of our company, in accordance with the city's urban plan, is in the process of searching for the best solution for moving this market to an appropriate location, which will, with its surface, access roads and infrastructure, correspond to the generally recognized standards (www.nstržnica.co.rs).

From the point of view of the object and purpose of the research it is necessary to point out that "gross quantitative markets" are inadequate, unregulated, infra- 
structurally undeveloped and they are surpassed places for wholesale trade in agroindustrial products. The aim is to prove that, at the national level, it is necessary to adopt a strategy for the development of wholesale markets as trade and public facilities that can provide conditions for higher consumption of fruits and vegetables, increase domestic production and development of the agro-industry sector, lower consumer prices and seasonal fluctuations with good infrastructure equipment as well efficient management system.

\section{Methods and assumptions of research}

The need to explore the effectiveness of wholesale trade in agro-industrial products is set as the basic element of the market position of these enterprises. The subject of research and control of the effects achieved is based on assumptions based on predetermined goals with what has been achieved as an integral element of trade, rates of return on investment, as well as the interests of customers and end-users of consumers. During the research for the purposes of this paper, among other methods, a comparative method of marketing research was used, which is a combination of historical methods and marketing research methods. The historical method implies our own knowledge, as well as a review of literature in the field of trade that discuss these oldest forms of trade. The method of marketing research involves the use of a questionnaire based on the subjects, objectives and assumptions of the research. Specific methods are analysis and synthesis, quantitative methods of statistical data processing, as well as methods of logical reasoning. Based on the goals of the research, the hypotheses on which the paper is based are defined, and they will enable the conducted research to make appropriate conclusions and recommendations. The hypotheses of the research are set as follows:

\section{H1: Wholesale markets will enable the increase in trade volume}

\section{$\mathrm{H} 2$ : Wholesale markets lead to an increase in overall economic effects}

H3: The wholesale market is a special market institution that has positive effects on buyers of agro-industrial products

Modern approach involves the use of wholesale markets as a special form of trade in order to achieve the goals of the company in the market, the greater volume of trade, the quality of the service provided as a competitive advantage in order to satisfy the interests of customers and end-users. As with other special market institutions, it is not possible to accurately determine the effects of the wholesale market regarding the size and extent of trade, due to the influence of other trading companies. On the basis of communication knowledge about the state of retail trade (gross quantitative markets), necessary research of these forms of trade has been carried out in our country, with special emphasis on JKP Tržnica Novi Sad (Kvantaška pijaca retail market). It is possible with "certain assumptions" to make a measurement of the effects of the wholesale market on the increased volume of trade, as well as the overall effects of the investment in the construction of the wholesale market. 


\section{Importance of wholesale markets for the development of trade in market-developed countries}

With the development of trade, the role and importance of wholesale markets has grown from the point of view of the development of competitive forms of trade, as well as from the point of view of the "urban" centers, like supplying large cities by fruits and vegetables as well as other products from the agro-industrial sector. By the end of the century, national and regional wholesale markets became the focal point for the distribution of (primarily) fruits and vegetables, but also cereals, cheese, dairy products meat, meat products, and other products important for certain countries and regions that have a special place in production, for instance, livestock, fish, dairy products, milk, flowers and consumer goods that can generally have a commercial as well as historical significance for the sale of products of a particular region.

With rapid urban growth in many parts of the world, wholesale markets will continue to play a vital role in channeling a wide range of products to urban consumers, despite the adoption of new techniques, such as the direct supply of supermarkets by farmers. Investments in the infrastructure of the wholesale markets will undoubtedly be increased over the years to come, but wholesale markets will not be a financial burden for governments, whether local or national. If they are well managed, they can be led professionally, and bring strong stimulus to the modernization of the food market as a whole(Ifoam,2014).

Bearing in mind that previous research has dealt with the comparative advantages of individual countries or groups of countries in relation to their position in the World Trade, the author introduces a new approach that follows the comparative advantages between the two countries, particularly in the specific market, as well as amongst competitors in the same market(Kuzman et al., 2016).

The total volume in the product market is 26 million tons a year, which is approximately $40 \%$ of Europe's fruit and vegetables ( 24 million tons a year), $10 \%$ of fish and fish products in Europe (1 million tons per year) and $2 \%$ of meat and meat supply to products in Europe (1 million tons per year) (Wuwm, 2016).

The development of trade, city infrastructure, competitive markets, wholesale markets, and development strategies are focused on the main transport roads at the edge of cities, for efficient transportation, avoiding traffic congestion, pollution and noise, as well as creating conditions for competitive advantage over other distribution centres. When it comes to wholesale markets as distribution centers, their role and significance in the future would increase in terms of taking over the role of auction and brokerage institutions so that they become central markets that can organize sales both directly and through their own warehouses and other specialized facilities With the aim of performing significant trade through other distribution centers. The significant role of wholesale markets in the marketing sense is also the position of the "brand" of the wholesale market as a recognizable channel of sales, promotion of goods, but also of public importance for the city in its center, as tourist, historical and other potentials that can contribute to the recognition and increase of trade in the region, and other major markets. 


\section{Research results}

The aim of the research was to collect general data in terms of ownership and business, as well as the time of sales of products on the Kvantaška pijaca market. The largest number of sellers is engaged in trade in fruits and vegetables and other agricultural products (Praća et al., 2017). The period of lease for utilization the slot at the Kvantaška pijaca market is for a longer period ranging from 1 year to 23 years. But it can be noted that this period is on average somewhat over 15 years. When it comes to business performance in the previous year, the company operated with a loss: $8 \%$ of the companies, the company covered costs but did not make a profit: $50 \%$ of the companies, the company operated successfully and made a profit: $20 \%$ of the companies. $22 \%$ of respondents did not answer the questions asked.

When it comes to exploring specific (special) attitudes, the results are as follows: the length of cooperation with the most important customers: $50 \%$ of respondents have cooperated for more than 5 years, $30 \%$ of respondents have cooperated from $5-10$ years and $20 \%$ have cooperated for more than 10 years. When asked if you are creating a customer database, $40 \%$ of the respondents are keeping it and $60 \%$ do not keep a customer database. As the most important form of rewarding the most important customers when it comes to individual customers, $80 \%$ of respondents think that the price reduction is the most important rewarding instrument, and $20 \%$ think it is the deferred payment. When it comes to companies, $60 \%$ think that quality of goods is the most important instrument, and $40 \%$ give a rebate on the purchased quantity of products.

As the most important instruments for controlling the operations of the surveyed companies, based on the questionnaire, the following are listed:

- Sales volume 1.7

- Profit 2.8

- Market share 2.9

- Liquidity 2.5

- Marketing Costs (Sales Promotion) 2.1 
Graph1.The most important instruments of business control(ranked 1-5; 1 as the most important)

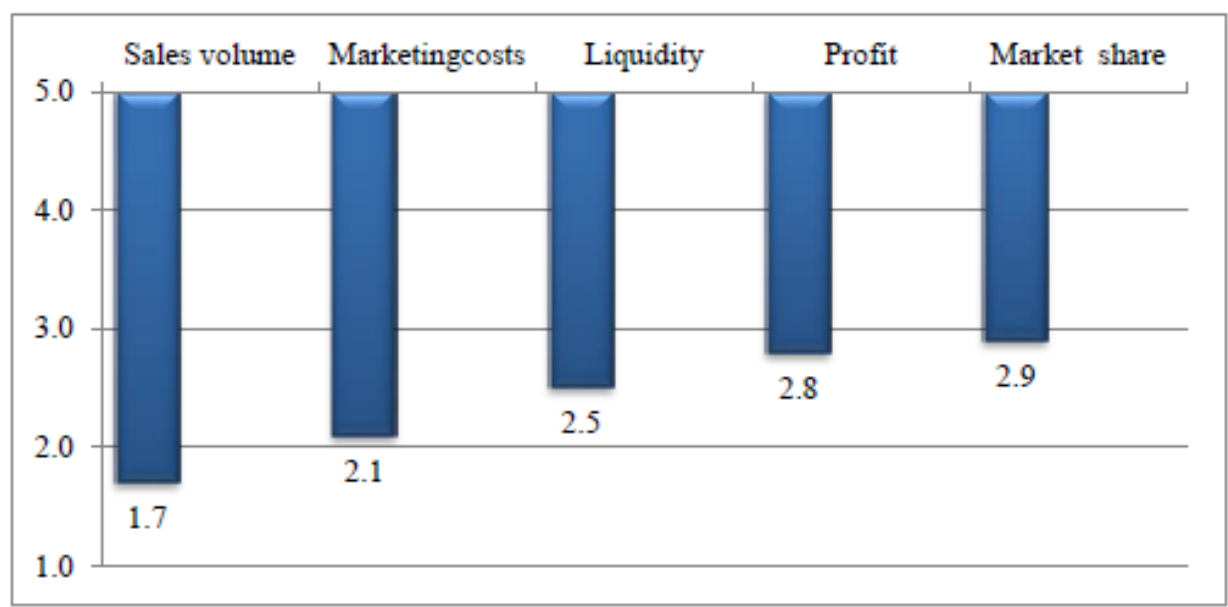

Source: Results of the survey conducted for the purposes of this paper at the Kvantaška pijaca Market in Novi Sad

Regarding the attitude of respondents about the terms of trade in the Kvantaška pijaca market, $40 \%$ answered positively, and $60 \%$ had a negative attitude towards the terms of sale. As the three biggest disadvantages for successful trade, the majority of the surveyedthink that these are, in the following order: 1 . Lack of funds, 2 . Infrastructure and market conditions of business, 3. Competition and lack of customers. When asked whether it is necessary to build a modern market facility - the type of wholesale market, $80 \%$ gave a positive answer, while $20 \%$ of them considered that it was not necessary to build such a facility. To the specific question which locations would you choose to build a wholesale market, the responses were, outside the city near the roads, Najlon pijaca (Novi Sad Nylon market) or near the Najlon pijaca market, near the motorway, at the current location. It should be noted that this question cannot give a more precise answer due to the lack of knowledge of real infrastructure, market and other conditions that are necessary for the construction of modern large-scale wholesale markets.

To the specific question of whether you would rent space in a new facility in the wholesale market, $40 \%$ of respondents did not want to make a statement, while $78 \%$ of respondents who gave the answer would rent a business space or other space, while $22 \%$ would not rent space at a new location. Asked if they would rent more space than the current occupancy, 33\% answered affirmatively, and $67 \%$ were satisfied with the present space for sale. 
Graph 2.The most important instrument of the market position of the company (1 - I totally disagree; 5 - I totally agree).

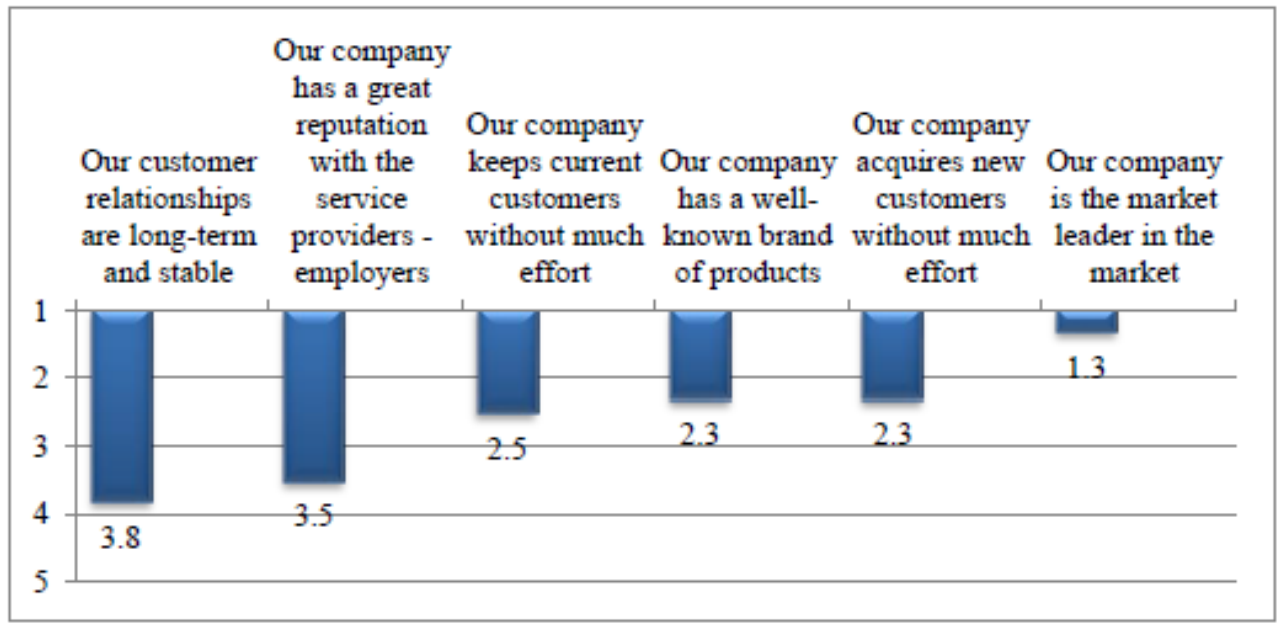

Source: Results of the survey conducted for the purposes of this paper at the Kvantaška pijaca Market in Novi Sad

Graph 3.The most important business instrument for the construction of a wholesale market

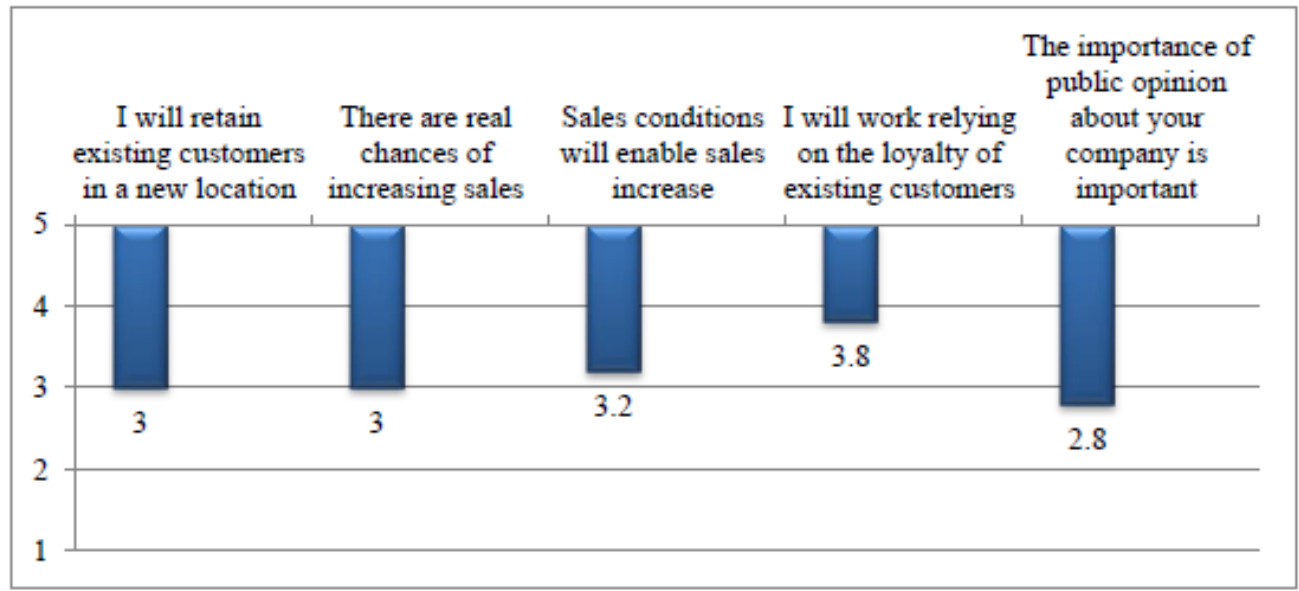

Source: Results of the survey conducted for the purposes of this paper at the Kvantaška pijaca Market in Novi Sad 
Graph 4.The attitudes of the respondents when it comes to construction and the level of services of the wholesale market

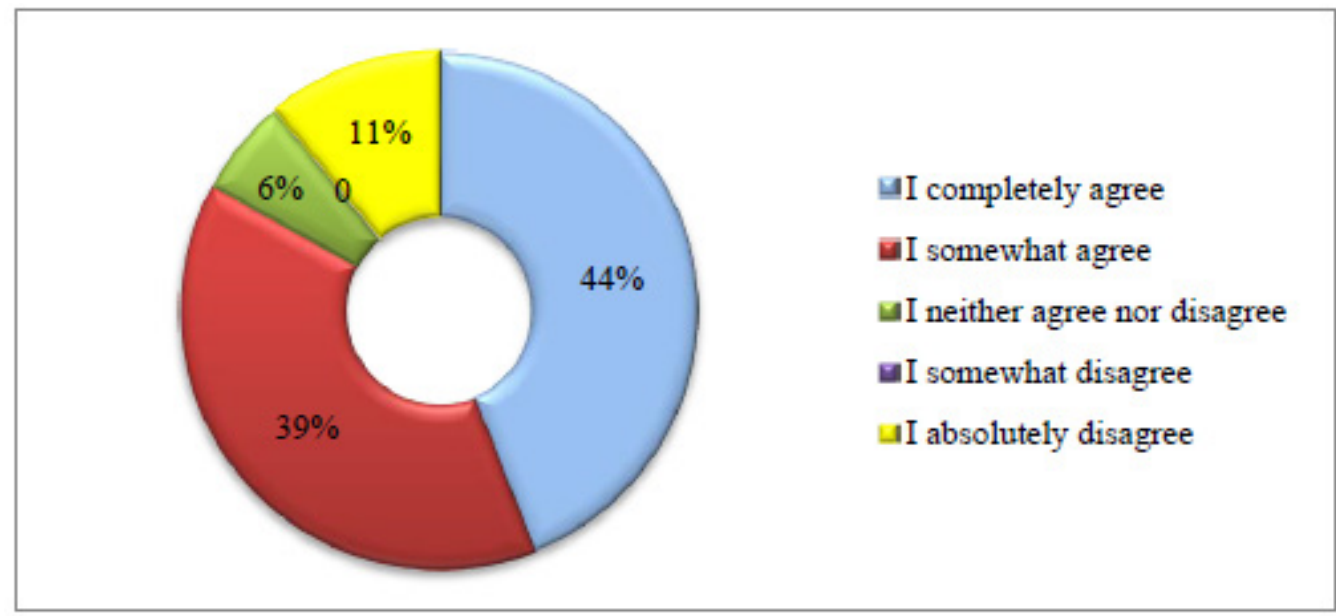

Source: Results of the survey conducted for the purposes of this paper at the Kvantaška pijaca Market in Novi Sad.

Graph 5.Seller's views on product quality

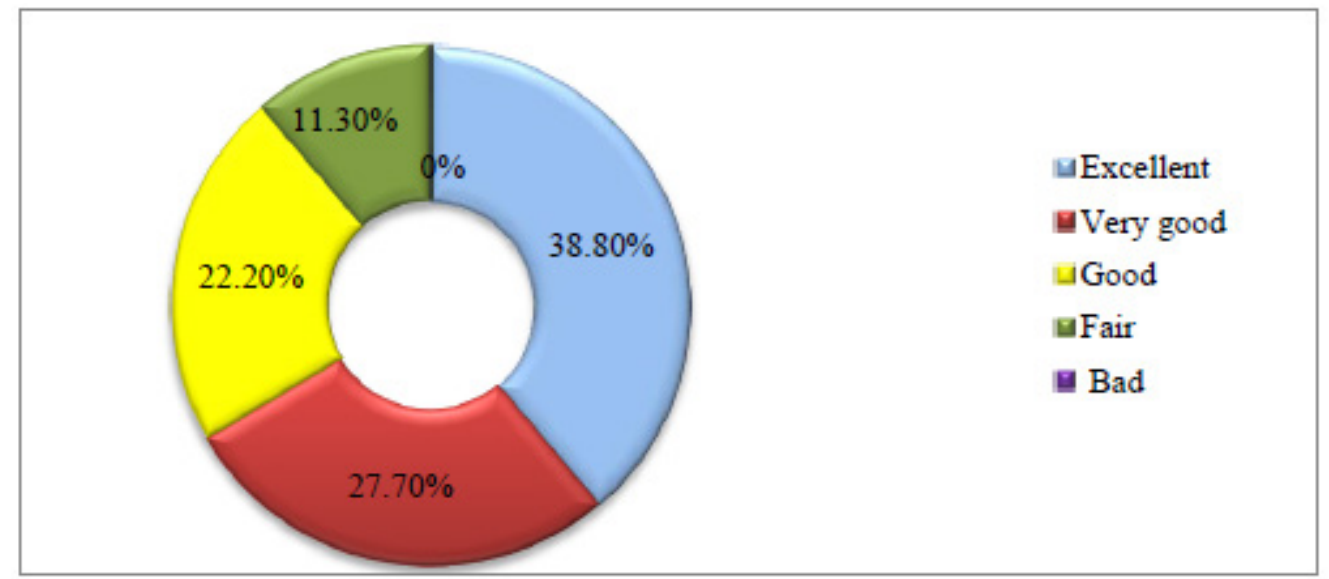

Source: Results of the survey conducted for the purposes of this paper at the Kvantaška pijaca Market in Novi Sad.

The construction of the wholesale market has real economic indicators as a public infrastructure object of urban and regional importance, as well as due to the constant interest of buyers for this type of trade, regardless of the increased presence of competing companies (Milanović et al., 2017).

Based on the conducted research, the development of trade in agro-industrial products through wholesale markets has real chances for the development of the agro-industrial complex. The conclusion is that the increased interest of tenants, customers and consumers provides a reliable basis for achieving the prerequisite for increasing of their needs, which are achieved 
by the construction of a modern wholesale market. On the basis of conducted surveys and statistical indicators, the total turnover of goods on the wholesale market would be increased by about $20 \%$ because of the increased interest of already existing tenants in the Kvantaška pijaca market. For $24 \%$ of the surveyed, the interest of buyers for trade would be increased by the construction of a modern, well-located and modernly equipped agro-industrial trade centre. Upon the basis of conducted research, contemporary consumers are more educated, better informed, more sophisticated, and therefore their needs are greater, but also the they know that the wholesale market facilities provide all the conditions for the purchase of a quality product with reasonable price in facilities that meet all the standards of trade, as well as the preservation and safety of food and agricultural food products. The conducted research has led to the conclusion that $30 \%$ of consumers would be more interested in purchasing in such modern facilities, easily accessible and supplied by products of agro-industry and other consumer goods that would enable them to maintain the level of competitive advantage as a distribution channel.

Table 1.Buyers' characteristics

\begin{tabular}{|lc|r|r|r|}
\hline \multicolumn{2}{|c|}{ Buyers' characteristics } & \multicolumn{2}{c|}{$\begin{array}{c}\text { Those who have visited } \\
\text { the marketplace }\end{array}$} & \multicolumn{2}{|c|}{$\begin{array}{c}\text { Those who have not } \\
\text { visited the marketplace }\end{array}$} & 4.008 & 4.509 \\
\hline 1. & Big & 501 & 2.445 & 2.934 \\
\hline 2. & Small & 489 & 11.110 & 12.120 \\
\hline 3. & Potential & 1.010 & 17.563 & 19.563 \\
\hline & TOTAL & 2.000 &
\end{tabular}

Source: Results of the survey conducted for the purposes of this paper at the Kvantaška pijaca Market in Novi Sad.

1. Small customers - buying less than $€ 1000$ in the previous year,

2. Large buyers - a purchase value greater than $€ 1000$,

3. Potential buyers - did not buy products from sellers

Communication stimulants can influence the decision making process of purchasers or consumers by different congruent levels(Prdić et al., 2014).

It is necessary to expand the range of products from the organic industry, to have a continuous supply and to develop adequate marketing (Vlahović et al., 2011).

The Lean concept is introduced into enterprise in order to creating value for the customers. The Lean reflects the strategic choice aimed to improve the competitiveness (Rao and Burgerstock, 2013). 
Table 2.Plans for purchase on the built wholesale market

\begin{tabular}{|l|c|c|}
\hline & Arithmetic mean* & Standard error \\
\hline Small customers & & 0.21 \\
\hline $\begin{array}{l}\text { Have visited the wholesale market } \\
\text { (seller) }\end{array}$ & $2.78(\mathrm{n}=180)$ & 0.17 \\
\hline $\begin{array}{l}\text { Have not visited the wholesale } \\
\text { market (seller) }\end{array}$ & $2.9(\mathrm{n}=172)$ & 0.15 \\
\hline Big customers & $2.87(\mathrm{n}=170)$ & 0.20 \\
\hline $\begin{array}{l}\text { Have visited the wholesale market } \\
\text { (seller) }\end{array}$ & $3.05(\mathrm{n}=160)$ & \\
\hline $\begin{array}{l}\text { Have not visited the wholesale } \\
\text { market (seller) }\end{array}$ & & 0.10 \\
\hline Potential buyers & $5.0(\mathrm{n}=199)$ & 0.10 \\
\hline $\begin{array}{l}\text { Have visited the wholesale market } \\
\text { (seller) }\end{array}$ & $5.0(\mathrm{n}=200)$ & \\
\hline $\begin{array}{l}\text { Have not visited the wholesale } \\
\text { market (seller) }\end{array}$ & & \\
\hline
\end{tabular}

$* 1$ - no plans; 5 - very defined plans, $\mathrm{n}=$ number of buyers

Source: Results of the survey conducted for the purposes of this paper at the Kvantaška pijaca Market in Novi Sad.

After positive views on the construction of the wholesale market, the survey was performed amongst the customers (visitors) who visited the Kvantaška pijaca Market, as well as amongst potential buyers who have not visited the point of sale in order to determine the impact of the wholesale market on the awareness of the existence of products and the interests of potential customers for the product. The research needs to determine the degree of awareness for the construction of the wholesale market and the interest in the products of the company. In this case it is necessary to apply a ranking scale from 1 to 5 where 1 represents the low interest (no purchasing intentions), while 5 is a very high interest for enterprise products (high purchasing intentions).

\section{Results and discussion}

The aim of the research is to show the state of the so-called wholesale trade markets in a systematic way with a special emphasis on the Kvantaška pijaca market owned by JPK Tržnica Novi Sad, which refers to the improvement of the processes and activities in the agrarian industry and the companies that provide services in the agricultural complex, which takes place through their comparison with the same or similar processes, which are happening in our country and throughout the world, which are objectively considered to be better, whether they are direct or indirect competitors.

Benchmarking against best identified practices, if suitably adopted and adapted, can generate a company considerable profit of performance within a very short time (Maire et al., 2005).

Speaking of hypotheses of the research, we conclude: 
H1: Wholesale markets lead to an increase in trade volume. The results of the qualitative research of the sellers at the Kvantaška pijaca Market show that the increase in the volume of trade is the most important factor of success, which in their opinion can be achieved and increased by the construction of a modern wholesale market, which will, along with the accompanying facilities, satisfy the interest of the sellers in the form of increasing profits, market share and other marketing instruments that will lead to an increase in sales. This hypothesis is confirmed by the views of domestic and foreign experts in the field of agroindustry, as well as the significance of the wholesale markets in the world in the development of the agro-industrial complex.

H2: Wholesale markets lead to an increase in overall economic effects. It was worthy to point out the importance of the development of these markets and public institutions and their importance to the overall economic and public infrastructure functions. It should be emphasized that the common interest of the city and the JKP Tržnica public company, which plans to build such a centre in a well-chosen economic and infrastructural location, coincides with the attitudes of the sellers who confirmed that such a centre would be of great importance for their businesses. When added to the fact that the customer and consumer attitudes are identical, as well as the knowledge that throughout the world the "wholesale markets" are considered some of the most important infra-structural facilities, the overall economic effects for the wholesale markets, sellers, customers and the wider social interests in the agro-industry is enormous.

H3: Wholesale market is a special market institution that has positive effects on buyers of agro-industrial products. The aim of the research was to confirm the hypothesis that, by the construction of a wholesale market, they will improve their processes and work, set new standards of work in the provision of services, which will contribute to better meeting of the demands of customers and will create a new value that will contribute that the wholesale market itself will excel out of competition. A special study of customer attitudes for the purposes of this paper found that they were very important in terms of purchasing and that their purchasing intentions of both permanent and potential buyers at the wholesale market were very pronounced and provided a realistic basis for building the wholesale market and associated services. They would increase their interest in shopping that would be enabled by sellers through the product quality, acceptable price, payment terms and other marketing instruments that would have potentially positive effects on buyers of agro-industrial products.

The market information system provides daily, updated data on the situation in various sectors of Serbian agriculture and may provide relevant data on market potentials and competition. To the question whether STIPS helps you make decisions in your business through a survey on the site or not, a response was provided by a 1361 visitors at the website. (Employer). The results were: that helps me a lot $45 \%$, it helps me $34 \%$, it does not help me $21 \%$. (STIPS)

The Target costs are defined as the difference between the anticipated price and required return. In practice, target profit often is driven by medium term corporate profit plans, which reflect the returns demanded by the financial markets (Woods et al., 2012) 


\section{Conclusion}

The aim of the research was to prove that the construction of the modern wholesale centre in Novi Sad would lead to an increase in trade in agro-industrial products, a replacement for the so-called quantitative markets (retail trade markets or gross sale markets), which are considered the informal places of wholesale trade in agro-industrial products. The significance of the wholesale market for agro-industrial products, based on the conducted research, is considered as an intended approach to the improvement of the process of trade and service activities. Their importance gives a realistic picture of the development of agroindustrial complexes, comparing them with large distribution chains and trade centres. It can be objectively and justifiably concluded that wholesale markets are considered the best places of trade for fruits and vegetables and other agricultural food products, as well as places for greater development of trade through auctions and stock exchanges and also as facilities for storing, packaging, maintaining products in modern cooling systems, for their sales and transportation. Therefore, the paper wishes to point out the importance of the wholesale market for agricultural food products, and the construction of modern facilities within the national trade strategy in the agro industrial complex. This paper would like to point out that the today's retail markets, are outdated, inadequate and unproductive centers of trade, and must be changed by the construction of a wholesale market, as a place with better trading conditions. Research conducted at the "Kvantaška pijaca Market" in Novi Sad has shown that the sellers want new standards in trade, in order to satisfy the interests of customers, but also expect a new additional value that will certainly result from the transition of trade to the wholesale market. The goal is, of course, achieving better conditions of trade in wholesale markets that can contribute to the increase of trade in terms of volume, quality, price for the buyer in relation to the competition. In essence, the conclusion is that trade in the wholesale market is a clear indicator of national, regional and city determination for the increase of their share in terms of satisfying the interests of the lessors, buyers, consumers and the city, which will, with the construction of the wholesale markets receive modern infrastructure centres with a wide range of mutual interests of economic and other institutions.

\section{References}

1. JKP Tržnica (available at: www.nstrznica.co.rs/kvantaška pijaca)

2. Kuzman, B., Stegić, M., Subić, J. (2016): Market oriented approach of revealed comparative advantage in international trade, Ekonomika poljoprivrede, Beograd, Vol, 63, No. 1, pp 247-260.

3. Lovreta,S. (2008):Strategija i politika razvoja trgovine Republike Srbije, Ekonomski fakultet, Beograd, NICEF, p. 245.

4. Maire, J.L., Bronet, V., Pillet, M. (2005): A typology of , best practices “ for a benchmarking process, Benchmarking: An International Journal, Vol. 12, No. 1, pp. 45 60, Emerald Group Publishing Limited, Bingley, UK.

5. Milanović, N., Andžić, S., Butulija, M. (2017): Struktura kapitala kao determinanta vrednosti preduzeća, Oditor, Vol. 3, No. 1, pp. 80-90. 
6. Milisavljević, M. (2010): Strategijski marketing, Ekonomski fakultet, Beograd,NICEF, p. 32 .

7. Praća, N., Paspalj, M., Paspalj, D. (2017): Ekonomska analiza uticaja savremene poljoprivrede na održivi razvoj, Oditor, Vol. 3, No. 1, pp. 37-51.

8. Prdić, N. (2016): Konkurentska prednost veletržnice kao kanala distribucije. Agroekonomika, Poljoprivredni fakultet univerziteta u Novom Sadu, No. 72, pp. 51-63.

9. Prdić, N., Kuzman, B., Barjaktarović, M. (2014):Practical research results of a successful company's appearance at the fair, Ekonomika Poljoprivrede, Beograd, Vol, 61, No. 4, pp. 903-914.

10. Rao, M., Bargerstock, A. (2013): Do Lean Implementation Initiatives Have Adequate Accounting Support? Do Debate of Duality, Managment Accounting Quarterly,Institute of Managment Accounting, Vol. 14, No. 4, pp. 12-21

11. Sistem tržišnih informacija poljoprivrede Srbije, Beograd, stipsvminpolj.gov.rs

12. The International Federation of Organic Agriculture Movements (IFOAM); (available at: www.ifoam.org),

13. Veletržnica Beograd, Belgrade wholesale market, (available at: www.veletrznica.co.rs);

14. Vlahović, B., Radojević, V., Živanić, I. (2011): Istraživanje stavova potrošača o potrošnji organske hrane u Srbiji, Ekonomika Poljoprivrede, Beograd, Vol, 58, No. 3, pp 443-455.

15. Vojnović, Ž., Zelenović, V., Cvijanović, D. (2017): Program of state support to agricultural crediting, Ekonomika Poljoprivrede, Beograd, Vol. 64, No. 1, pp. 339-358.

16. Woods, M., Taylorb, L., Cheng Ge Fangc, G. (2012): Electromicy: A case study of economic value added costing, Management Accounting Research, Elsevier Science Ltd., Vol. 23, No. 4, pp. 261-277.

17. WUWM (World Union of Wholesale Markets), Promoting wholesale and retail markets word-wide, accessed October, 2016.

18. Zakon o trgovini Republike Srbije (available at: www.mtt.gov.rs/download/1(2)/ zakon_o trgovini.pdf) 


\section{ZNAČAJ VELETRŽNICE ZA TRGOVINU AGROINDUSTRIJSKIM PROIZVODIMA}

\section{Sažetak}

Osnovni cilj istraživanja zasniva se na značaju koje veletržnice kao posebne tržišne institucije imaju u trgovini agroindustrijskim proizvodima. Na osnovu komunikacijskih saznanja o poslovanju tržnica na malo (kvantaške pijace), na domaćem tržištu, kao i značaja koji se u razvijenim zemljama pridaje veletržnicama sa aspekta trgovine, dolazi se do zaključka da i domaća trgovina, razvojem veletržnica (trgovina na veliko) može povećati prodaju ovih proizvoda. Predmet istraživanja ovog rada jeste koncept izgradnje veletržnica kao zamene za trgovinu na malo (kvantaške pijace) agroindustrijskim proizvodima. Radom se želi postići takav nivo saznanja koji će omogućiti donošenje kvalitetnih odluka polazeći odinteresa preduzeća, trgovaca i kupaca (potrošača).

Ključne reči:tržište, trgovina, agroindustrijski proizvodi, veletržnica 